\title{
Perceptions and knowledge of telemedicine in Ecuadorian practicing physicians: an instrument adaptation, validation and translation from English to Spanish
}

Geovanny Alvarado-Villa, Christian KuonYeng-Escalante, Nicolás Sagñay-Pinilla, Carlos Vera Paz and Ivan Cherrez-Ojeda*

\begin{abstract}
Background: During the COVID-19 pandemic, multiple countries have taken measures, such as isolation and quarantine, to prevent person-to-person spread of disease. These actions forced many physicians to adopt new techniques, such as telemedicine, to continue patient care, which has proven to be useful in continued care for those with non-COVID-19 pathologies. Various factors, such as security, confidentiality, cost-effectiveness, comfort, and the risk of malpractice, influence the perception of telemedicine among medical practitioners. The aim of this study was to adapt an existing instrument and validate it into a new Spanish version. The instrument is about the perceptions and knowledge of telemedicine in healthcare professionals.

Methods: The original questionnaire surveyed 6 domains with 40 questions, and each question was measured with a fivepoint Likert scale ranging from very high [5] to very low [1]. The survey was translated to Spanish using machine translation. The translation was reviewed independently, and then, a consensus was achieved regarding minor changes in the syntax of the survey to facilitate understanding. After expert feedback and questionnaire review, the research team members proposed reducing the instrument to 13 items in 4 domains due to the similarity of some questions. The sample was divided into 2randomly selected groups. Eligibility criteria included physicians providing private or public services with active medical/ clinical practice.

Results: In total, 382 surveys were collected and separated into two random samples, S1 and S2 (198 and 184, respectively). In exploratory factor analysis (EFA), the 13 items were grouped into four theoretical domains, and item 7 presented cross loading between factors and was removed. Confirmatory factor analysis was performed to assess the scale reliability and interscale associations; three models were tested. Global Cronbach's alpha for internal consistency was 0.76 for the EFA. The goodness of fit measures root mean square error of approximation and comparative fit index were 0.009 and 0.999 , respectively, for the best model.
\end{abstract}

\footnotetext{
*Correspondence: ivancherrez@gmail.com

Universidad Espíritu Santo, Samborondón, Ecuador
} 
Conclusions: The translated instrument was clear, with adequate internal consistency, readability, and appropriate for application in the physician setting. This validated questionnaire made it possible to evaluate physicians' knowledge of telemedicine to increase its use, especially during the COVID-19 pandemic.

Keywords: Telemedicine, Healthcare, Questionnaire, Perceptions

\section{Background}

The use of information and communication technologies (ICTs) in healthcare has significantly changed the physician-patient relationship [1]. Telemedicine is the implementation of ICTs to deliver distant medical care [2]. During the COVID-19 pandemic, multiple countries took public health measures. Isolation and quarantine were community containment plans to prevent person-to-person spread of disease [3]. This unique situation forced many physicians to adopt new techniques to continue patient care [4]. Telemedicine has proven to be a useful tool during the pandemic. As a result, it has been used in the assessment and triage of patients with COVID-19 to reduce healthcare load. Nevertheless, it has proven to be useful for the continued care of those with non-COVID-19 pathologies [5-7]. In addition, telemedicine may reduce costs due to decreased prolonged hospital stays [8].

Adaptation to new technologies is generally a process of constant cost-benefit evaluation [9]. For instance, various factors, such as security, confidentiality, costeffectiveness, comfort, and the risk of malpractice, influence the perception of medical practitioners [10]. Kuo et al. (2015) described several factors, such as attitude, subjective norms, and perceived behavioral control, that could affect the intention of physicians to adopt new technologies [11].

There are some validated English instruments for evaluating physicians' perceptions that were not selected. These questionnaires focus on specialized subjects regarding perceptions and knowledge of telemedicine, such as telerehabilitation $[12,13]$, and they are designed for specific medical specialties. Ayatollahi et al. [10] talks about the perceptions and knowledge of telemedicine in general terms, this is the reason why it was selected by the investigators for the adaptation into Spanish and generate a new instrument.

The appropriate assessment of clinician knowledge and perceptions of telemedicine is essential. Therefore, this study created a reliable tool that can detect changes in physicians' perceptions of the use of telemedicine in the future $[14,15]$. The aim of this study was to adapt an existing instrument and validate it into a new Spanish version. The instrument is about the perceptions and knowledge of telemedicine in healthcare professionals.

\section{Methods}

Study design

All methods were carried out in accordance with relevant guidelines and regulations. The study was conducted in Ecuadorian physicians, for 6 weeks in a period between march 23rd to may 11th of 2020. Surveys collected were recorded in a standardized database for process and statistical analysis. Data security and protection was preserved at all points during the process. Eligibility criteria included physicians providing private or public services with active medical/clinical practice. The eligibility criteria excluded non-Ecuadorian physicians, because the aim was to adapt a questionnaire based on the region. The sample size was determined by multiplying the number of questions (13 items) by 5 (lower limit) and 20 (upper limit), yielding a needed sample size of 65 to 250 doctors, as proposed by Suhr (2005) and other validation studies in an Ecuadorian population [16-19]. The population for this investigation was selected by a nondiscriminative selective snowball sampling method, because of social distancing due to COVID-19 pandemic. The instrument was provided on webinars and allowed the recruitment of 404 physicians.

The original questionnaire included 6 domains with 40 questions, and each question was measured with a fivepoint Likert scale ranging from very high [5] to very low [1] [10]. The authors do not consider demographic characteristics as a domain because they do not measure a construct. Yang et al. (2018) proposed a model for the adoption of machine translations (MTs) [20]. Consequently, the survey was translated into Spanish using MT. The translation was reviewed independently by each research team member, and then, a consensus was achieved regarding minor changes needed in the syntax of the survey to facilitate understanding.

The translated instrument was converted into a Google Form survey and was implemented as a pilot test among 65 physicians. The survey objective was to ensure that the vocabulary, understanding, design, and time needed to complete the survey were appropriate enough to ensure stability and comprehension [21].

After the expert feedback and questionnaire indicators that resulted in the pilot test, the research team members proposed reducing the instrument to 13 items in 4 domains. Three domains were modified or excluded: "Clinicians' perception of the advantages of telemedicine technology", "Clinicians' perception of the telemedicine 
technology ease of use" and "Clinicians' perception of the necessity of telemedicine technology". The former was modified because physicians do not receive training on the use of ICTs and the similarity between some questions of this domains and some questions of the remain domains. The second one was modified and changed to "Perception of the utility of telemedicine". In the same way, questions that could not be used due to differences in administrative characteristics (budget management, conferences, training or guidelines) were excluded. From the original instrument "Clinicians' perception of the advantages of telemedicine technology" and "Clinicians' perception of the necessity of telemedicine technology" were excluded.

The questionnaire was completed by 404 participants, and 22 of them were excluded because they were not Ecuadorian. The sample was divided into 2 randomly selected groups. The first group consisted of 198 doctors for sample 1 (S1) to perform exploratory factor analysis (EFA). The second group included 184 doctors for sample 2 (S2) for confirmatory factor analysis (CFA).

\section{Statistical analysis}

\section{Descriptive analyze}

A descriptive statistical analysis was implemented for sociodemographic data. Qualitative variables are presented as frequencies and percentages, and quantitative variables are presented as the means and standard deviations. Each item was measured using its mean response value. Age, sex, educational level, and workplace were used as independent variables in each analysis. They were examined using skewness and kurtosis for normality. Statistical significance was considered as a $p<0.05$. All statistical analyses were performed using SPSS for Windows (version 25.0; SPSS Inc., Chicago, Illinois).

\section{Psychometric analysis}

The Kaiser-Meyer-Olkin (KMO) measure was calculated to evaluate the sampling adequacy of each item on the anti-image of the correlation matrix [22]. All sampling measure cutoff points were set at 0.5 [22]. Bartlett's test of sphericity indicated that the analysis was suitable for the scale [23]. Commonality analysis was performed, and after this procedure, the questionnaire was reduced to ensure construct parsimony and usability.

The scale structure was determined by several indicators. Initially, eigenvalues were extracted. A factor structure with eigenvalues above 1 was selected as the criterion for EFA. Maximum likelihood estimation (MLE) was performed and supported the reduction of the instrument to 4 domains: "Knowledge about telemedicine", "Perception of the utility of telemedicine", "Perception of the disadvantages of telemedicine", and "Knowledge of the security of telemedicine". The chi square showed a nonsignificant result, supporting the MLE.

The internal consistency was calculated by Cronbach's alpha for both the full scale and for each of the subscales

Table 1 Sociodemographic characteristics of the population

\begin{tabular}{|c|c|c|c|c|c|}
\hline \multirow[t]{2}{*}{ Variables } & & \multicolumn{2}{|l|}{ S1 } & \multicolumn{2}{|l|}{ S2 } \\
\hline & & Frequency (n) & Percentage (\%) & Frequency $(n)$ & Percentage (\%) \\
\hline \multirow[t]{2}{*}{ Sex } & Male & 115 & 58.1 & 109 & 59.2 \\
\hline & Female & 83 & 41.9 & 75 & 40.8 \\
\hline \multirow[t]{2}{*}{ Employment type } & Permanent & 174 & 87.9 & 165 & 89.7 \\
\hline & Temporary & 24 & 12.1 & 19 & 10.3 \\
\hline \multirow[t]{4}{*}{ Education level } & General doctor & 42 & 21.2 & 46 & 25 \\
\hline & Medical specialist & 132 & 66.7 & 123 & 66.8 \\
\hline & Master's degree & 13 & 6.6 & 7 & 3.8 \\
\hline & $\mathrm{PhD}$ & 11 & 5.6 & 8 & 4.3 \\
\hline \multirow[t]{5}{*}{ Work experience (years) } & $1-5$ & 19 & 9.6 & 16 & 8.7 \\
\hline & $6-10$ & 21 & 10.6 & 19 & 10.3 \\
\hline & $11-15$ & 23 & 11.6 & 30 & 16.3 \\
\hline & $16-20$ & 25 & 12.6 & 25 & 13.6 \\
\hline & Over 20 & 110 & 55.6 & 94 & 51.1 \\
\hline \multirow[t]{4}{*}{ Workplace } & Hospital & 60 & 30.3 & 42 & 22.8 \\
\hline & Clinic & 47 & 23.7 & 46 & 25 \\
\hline & Both & 36 & 18.2 & 38 & 20.7 \\
\hline & Other & 55 & 27.8 & 58 & 31.5 \\
\hline
\end{tabular}


found in the EFA. Cronbach's alpha measures the interrelation of the items, with values ranging between 0 and 1 [24]. The results above the threshold of $>0.7$ were considered acceptable. A value $>0.9$ suggests redundancies, indicating that the instrument should be shortened [25].

Other tests were used to indicate goodness of fit: Chi square, root mean square error of approximation (RMSEA: range $0-1$, with a recommended result $\leq 0.06$ ), normed fit index (NFI: range $0-1$, with a recommended result $>0.90$ ), Tucker Lewis index (TLI: $0-1$, with a recommended result $>0.90$ ), comparative fit index (CFI: range $0-1$, with a recommended result $>0.90$ ), parsimony ratio (range $0-1$, with a recommended result of approximately 1), parsimony NFI (PNFI: range $0-1$, with a recommended result $>0.50$ ), and parsimony CFI (PCFI: range $0-1$, with a recommended result $>0.50)[26,27]$.

\section{Readability}

The Fernandez-Huerta index and Crawford index were used to assess readability and estimate grade level, respectively. Scores were reported in a range of 0-100, with higher results indicating greater readability, and a result of 60-70 represented easy understanding for the population of $\sim 15$ years old [28].

\section{Results}

With a response rate of $95 \%, 382$ participants completed the survey. Two hundred twenty-four of the participants were male $(58.6 \%)$. Most of the participants had a permanent job $(88,7 \%)$. Approximately $66.8 \%$ of the physicians were medical specialists, and $22.3 \%$ are currently working as primary care physicians. Their workplace was separated in almost equal percentages: hospital with $23 \%$, clinic $24.3 \%$, both hospital and clinic with $23.6 \%$,

Table 2 Descriptive statistics of the items of the proposed instrument

\begin{tabular}{|c|c|c|c|c|c|c|c|c|c|c|c|}
\hline \multirow[t]{2}{*}{ Item } & & \multirow{2}{*}{$\begin{array}{l}1 \\
\text { Very low }\end{array}$} & & \multirow{2}{*}{$\begin{array}{l}3 \\
\text { Average }\end{array}$} & \multirow{2}{*}{$\begin{array}{l}4 \\
\text { High }\end{array}$} & 5 & \multirow[t]{2}{*}{ Mean } & \multirow[t]{2}{*}{ SD } & \multirow[t]{2}{*}{ Median } & \multirow[t]{2}{*}{ Skewness } & \multirow[t]{2}{*}{ Kurtosis } \\
\hline & & & & & & Very high & & & & & \\
\hline \multirow[t]{2}{*}{1} & Frequency (n) & 81 & 97 & 126 & 62 & 16 & 2.57 & 3 & 1.12 & 0.17 & -0.76 \\
\hline & Percentage (\%) & $21.2 \%$ & $25.4 \%$ & $33.0 \%$ & $16.2 \%$ & $4.2 \%$ & & & & & \\
\hline \multirow[t]{2}{*}{2} & Frequency (n) & 86 & 115 & 115 & 55 & 11 & 2.45 & 2 & 1.08 & 0.28 & -0.70 \\
\hline & Percentage (\%) & $22.5 \%$ & $30.1 \%$ & $30.1 \%$ & $14.4 \%$ & $2.9 \%$ & & & & & \\
\hline \multirow[t]{2}{*}{3} & Frequency (n) & 88 & 106 & 125 & 51 & 12 & 2.46 & 2 & 1.08 & 0.25 & -0.67 \\
\hline & Percentage (\%) & $23.0 \%$ & $27.7 \%$ & $32.7 \%$ & $13.4 \%$ & $3.1 \%$ & & & & & \\
\hline \multirow[t]{2}{*}{4} & Frequency (n) & 48 & 67 & 109 & 124 & 34 & 3.08 & 3 & 1.16 & -0.29 & -0.80 \\
\hline & Percentage (\%) & $12.6 \%$ & $17.5 \%$ & $28.5 \%$ & $32.5 \%$ & $8.9 \%$ & & & & & \\
\hline \multirow[t]{2}{*}{5} & Frequency (n) & 62 & 64 & 136 & 89 & 31 & 2.90 & 3 & 1.17 & -0.12 & -0.77 \\
\hline & Percentage (\%) & $16.2 \%$ & $16.8 \%$ & $35.6 \%$ & $23.3 \%$ & $8.1 \%$ & & & & & \\
\hline \multirow[t]{2}{*}{6} & Frequency (n) & 91 & 90 & 131 & 55 & 15 & 2.51 & 3 & 1.12 & 0.19 & -0.76 \\
\hline & Percentage (\%) & $23.8 \%$ & $23.6 \%$ & $34.3 \%$ & $14.4 \%$ & $3.9 \%$ & & & & & \\
\hline \multirow[t]{2}{*}{7} & Frequency (n) & 34 & 51 & 120 & 122 & 55 & 3.30 & 3 & 1.14 & -0.37 & -0.53 \\
\hline & Percentage (\%) & $8.9 \%$ & $13.4 \%$ & $31.4 \%$ & $31.9 \%$ & $14.4 \%$ & & & & & \\
\hline \multirow[t]{2}{*}{8} & Frequency (n) & 94 & 93 & 89 & 71 & 35 & 2.63 & 3 & 1.28 & 0.27 & -1.03 \\
\hline & Percentage (\%) & $24.6 \%$ & $24.3 \%$ & $23.3 \%$ & $18.6 \%$ & $9.2 \%$ & & & & & \\
\hline \multirow[t]{2}{*}{9} & Frequency (n) & 53 & 83 & 106 & 93 & 47 & 2.99 & 3 & 1.23 & -0.04 & -0.95 \\
\hline & Percentage (\%) & $13.9 \%$ & $21.7 \%$ & $27.7 \%$ & $24.3 \%$ & $12.3 \%$ & & & & & \\
\hline \multirow[t]{2}{*}{10} & Frequency (n) & 44 & 68 & 99 & 103 & 68 & 3.22 & 3 & 1.26 & -0.22 & -0.95 \\
\hline & Percentage (\%) & $11.5 \%$ & $17.8 \%$ & $25.9 \%$ & $27.0 \%$ & $17.8 \%$ & & & & & \\
\hline \multirow[t]{2}{*}{11} & Frequency (n) & 10 & 27 & 58 & 105 & 182 & 4.10 & 4 & 1.07 & -1.08 & 0.40 \\
\hline & Percentage (\%) & $2.6 \%$ & $7.1 \%$ & $15.2 \%$ & $27.5 \%$ & $47.6 \%$ & & & & & \\
\hline \multirow[t]{2}{*}{12} & Frequency (n) & 9 & 24 & 58 & 107 & 184 & 4.13 & 4 & 1.04 & -1.11 & 0.54 \\
\hline & Percentage (\%) & $2.4 \%$ & $6.3 \%$ & $15.2 \%$ & $28.0 \%$ & $48.2 \%$ & & & & & \\
\hline \multirow[t]{2}{*}{13} & Frequency (n) & 11 & 19 & 59 & 128 & 165 & 4.09 & 4 & 1.02 & -1.13 & 0.84 \\
\hline & Percentage (\%) & $2.9 \%$ & $5.0 \%$ & $15.4 \%$ & $33.5 \%$ & $43.2 \%$ & & & & & \\
\hline
\end{tabular}


Table 3 Factor Analysis Pattern Matrix

\begin{tabular}{|c|c|c|c|c|}
\hline \multirow[t]{2}{*}{ Questions } & \multicolumn{4}{|c|}{ Domains } \\
\hline & 1 & 2 & 3 & 4 \\
\hline 1 & 0.910 & & & \\
\hline 2 & 0.983 & & & \\
\hline 3 & 0.824 & & & \\
\hline 4 & & & 0.786 & \\
\hline 5 & & & 0.825 & \\
\hline 6 & & & 0.790 & -0.380 \\
\hline 7 & & 0.476 & 0.601 & \\
\hline 8 & & & & 0.774 \\
\hline 9 & & & & 0.741 \\
\hline 10 & & & & 0.782 \\
\hline 11 & & 0.922 & & \\
\hline 12 & & 0.945 & & \\
\hline 13 & & 0.927 & & \\
\hline
\end{tabular}

private practice with $20.9 \%$ and others with $8.1 \%$. The 382 surveys were collected and separated into two random samples, S1 and S2 (198 and 184, respectively). EFA and CFA was performed in S1 and S2, respectively (see Table 1).

\section{Descriptive}

Individual items were expected to be non-normal. Consistent with this, the skewness ranged from -1.13 (item 13) to 0.28 (item 2). The kurtosis ranged from - 1.03 (item 8 ) to 0.84 (item 13). Individual items also had median values ranging from 1.02 (item 13) to 1.28 (item 8).
The clinicians' knowledge about telemedicine is limited, according to item 1, 33\% (average) and 25.4\% (low), item 2, 30.1\% (average) and 30.1\% (low) and item 3, 32.7\% (average) and $27.7 \%$ (low). The perceptions of the utility of telemedicine was average, according to item 4, 32.5\% (high) and 28.5\% (average), item 5, 35.6\% (average) and $23.3 \%$ (high) and item 6, 343\% (average) and 23.8\% (very low) (see Table 2).

\section{Exploratory factor analysis}

The Cronbach's alpha for the pilot test was 0.94. In the EFA, the 13 items were grouped into four theoretical domains, and item 7 "To what extent does ease of use of telemedicine technology facilitate its learning?" presented cross loading between factors and was removed. However, item removal at this stage did not improve the reliability statistics (see Table 3 ). The global Cronbach's alpha for internal consistency was 0.76 .

\section{Confirmatory factor analysis}

CFA was performed to assess scale reliability and interscale associations. Three models (M1, M2, M3) were tested to determine the best reliability (see Tables 4 and 5). The removal of item 7 at this stage provided the best goodness of fit measures for the final model. Goodness of fit measures are shown in Table 5 (see Table 6). Figure 1 shows the results for model 3 with RMSEA and CFI values of 0.009 and CFI 0.999, respectively (see Fig. 1).

\section{Readability}

A readability analysis was conducted. The results showed a Fernandez-Huerta score of 52.6 and a

Table 4 Comparison of Cronbach's alphas of the three models, with Model 3 excluding item 7

\begin{tabular}{|c|c|c|c|c|}
\hline \multicolumn{3}{|l|}{ Sample 1} & \multicolumn{2}{|l|}{ Sample 2} \\
\hline Questions & $\begin{array}{l}\text { Cronbach's Alpha per domain- } \\
\text { Model } 1\end{array}$ & $\begin{array}{l}\text { Total Cronbach's Alpha- } \\
\text { Model } 1\end{array}$ & $\begin{array}{l}\text { Cronbach's Alpha per domain- } \\
\text { Model } 2\end{array}$ & $\begin{array}{l}\text { Total Cronbach's Alpha- } \\
\text { Model } 2\end{array}$ \\
\hline 1 & 0.93 & 0.76 & 0.942 & 0.742 \\
\hline \multicolumn{5}{|l|}{2} \\
\hline \multicolumn{5}{|l|}{3} \\
\hline 4 & 0.834 & & 0.803 & \\
\hline \multicolumn{5}{|l|}{5} \\
\hline \multicolumn{5}{|l|}{6} \\
\hline \multicolumn{5}{|l|}{7} \\
\hline 8 & 0.807 & & 0.772 & \\
\hline \multicolumn{5}{|l|}{9} \\
\hline \multicolumn{5}{|l|}{10} \\
\hline 11 & 0.952 & & 0.947 & \\
\hline \multicolumn{5}{|l|}{12} \\
\hline 13 & & & & \\
\hline
\end{tabular}


Table 5 Cronbach's alpha of model 3

\begin{tabular}{|c|c|c|c|}
\hline Domains & Questions & $\begin{array}{l}\text { Cronbach's Alfa per } \\
\text { domains-Model } 3\end{array}$ & $\begin{array}{l}\text { Total Cronbach's } \\
\text { Alfa-Model } 3\end{array}$ \\
\hline \multirow{6}{*}{$\begin{array}{l}\text { Knowledge about } \\
\text { telemedicine }\end{array}$} & 1. ¿En qué medida está familiarizado con la telemedicina? & \multirow[t]{6}{*}{0.942} & \multirow[t]{6}{*}{0.715} \\
\hline & To what extent are you familiar with telemedicine technology? & & \\
\hline & $\begin{array}{l}\text { 2. ¿En qué medida está familiarizado con las aplicaciones médicas de la } \\
\text { telemedicina? }\end{array}$ & & \\
\hline & $\begin{array}{l}\text { To what extent are you familiar with the medical applications of telemedicine } \\
\text { technology? }\end{array}$ & & \\
\hline & $\begin{array}{l}\text { 3. ¿En qué medida está familiarizado con las herramientas de la } \\
\text { telemedicina? }\end{array}$ & & \\
\hline & To what extent are you familiar with telemedicine tools? & & \\
\hline \multirow[t]{6}{*}{$\begin{array}{l}\text { Perception of the utility of } \\
\text { telemedicine }\end{array}$} & $\begin{array}{l}\text { 4. En su opinión, ¿En qué medida la telemedicina es efectiva para reducir } \\
\text { los costos de la atención al paciente en los hospitales? }\end{array}$ & \multirow[t]{6}{*}{0.833} & \\
\hline & $\begin{array}{l}\text { In your opinion, to what extent is telemedicine effective in reducing the costs of } \\
\text { patient care in hospitals? }\end{array}$ & & \\
\hline & $\begin{array}{l}\text { 5. En su opinión, ¿En qué medida la tecnología de telemedicina ahorra } \\
\text { tiempo a los médicos? }\end{array}$ & & \\
\hline & $\begin{array}{l}\text { In your opinion, to what extent does telemedicine technology save clinicians' } \\
\text { time? }\end{array}$ & & \\
\hline & $\begin{array}{l}\text { 6. En su opinión, ¿En qué medida la tecnología de telemedicina } \\
\text { proporciona una atención médica mejor y más rápida? }\end{array}$ & & \\
\hline & $\begin{array}{l}\text { In your opinion, to what extent does telemedicine technology provide faster } \\
\text { and better medical care? }\end{array}$ & & \\
\hline \multirow{6}{*}{$\begin{array}{l}\text { Perception of the } \\
\text { disadvantages of } \\
\text { telemedicine }\end{array}$} & $\begin{array}{l}\text { 7. En su opinión, ¿En qué medida la tecnología de telemedicina pone en } \\
\text { peligro la privacidad del paciente? }\end{array}$ & \multirow[t]{6}{*}{0.772} & \\
\hline & $\begin{array}{l}\text { In your opinion, to what extent does telemedicine technology endanger patient } \\
\text { privacy? }\end{array}$ & & \\
\hline & $\begin{array}{l}\text { 8. En su opinión, ¿En qué medida la tecnología de telemedicina reduce la } \\
\text { eficiencia de la atención al paciente? }\end{array}$ & & \\
\hline & $\begin{array}{l}\text { In your opinion, to what extent does telemedicine technology reduce the } \\
\text { efficiency of patient care? }\end{array}$ & & \\
\hline & $\begin{array}{l}\text { 9. En su opinión, ¿En qué medida la tecnología de telemedicina aumenta la } \\
\text { mala práctica médica? }\end{array}$ & & \\
\hline & $\begin{array}{l}\text { In your opinion, to what extent may telemedicine technology increase } \\
\text { malpractice in healthcare? }\end{array}$ & & \\
\hline \multirow[t]{6}{*}{$\begin{array}{l}\text { Knowledge of the security } \\
\text { of telemedicine }\end{array}$} & $\begin{array}{l}\text { 10. ¿En qué medida se debe crear un marco para evitar la violación de la } \\
\text { confidencialidad de los datos cuando se utiliza la telemedicina? }\end{array}$ & \multirow[t]{6}{*}{0.947} & \\
\hline & $\begin{array}{l}\text { To what extent should a framework be created to prevent breaching data } \\
\text { confidentiality when using telemedicine? }\end{array}$ & & \\
\hline & $\begin{array}{l}\text { 11. ¿En qué medida la tecnología de telemedicina requiere una aclaración } \\
\text { legal para los pacientes? }\end{array}$ & & \\
\hline & $\begin{array}{l}\text { To what extent does telemedicine technology require legal clarification for } \\
\text { patients? }\end{array}$ & & \\
\hline & $\begin{array}{l}\text { 12. ¿En qué medida la tecnología de telemedicina requiere un marco } \\
\text { formulado y claro para acceder a la información médica? }\end{array}$ & & \\
\hline & $\begin{array}{l}\text { To what extent does telemedicine technology require a formulated and clear } \\
\text { framework for access to medical information? }\end{array}$ & & \\
\hline
\end{tabular}

Crawford grade level of 6.6 [29]. These results indicated that these items were likely to be understandable by a typical 14- to 15-year-old individual and required a minimum of 6 years of schooling.

\section{Discussion}

The results of this validation study achieved a parsimonious and reliable instrument. The results can be used to rapidly assess perceptions of new technology using 
Table 6 Goodness of fit measures for Model 1, Model 2 and Model 3

\begin{tabular}{|c|c|c|c|c|c|c|c|c|}
\hline \multirow[b]{2}{*}{ Models } & \multicolumn{2}{|c|}{ Absolute adjustment measures } & \multicolumn{3}{|c|}{ Incremental adjustment measures } & \multicolumn{3}{|c|}{ Parsimony adjustment measures } \\
\hline & Chi Square & RMSEA (IC) & NFI & TLI & CFI & PRATIO & PNFI & PCFI \\
\hline M1 & 0.002 & $0.057(0.034-0.078)$ & 0.939 & 0.970 & 0.976 & 0.782 & 0.735 & 0.763 \\
\hline M2 & 0.176 & $0.032(0.000-0.060)$ & 0.961 & 0.992 & 0.994 & 0.758 & 0.728 & 0.753 \\
\hline M3 & 0.443 & 0.009 (0.000-0.049) & 0.968 & 0.999 & 0.999 & 0.727 & 0.704 & 0.727 \\
\hline
\end{tabular}

data derived from a large cohort of medical practitioners. Several studies have concluded that the length of questionnaires has an inverse relation with the response rate [30,31]. Due to the time constraints of physicians, the questionnaire was designed to be short and feasible.

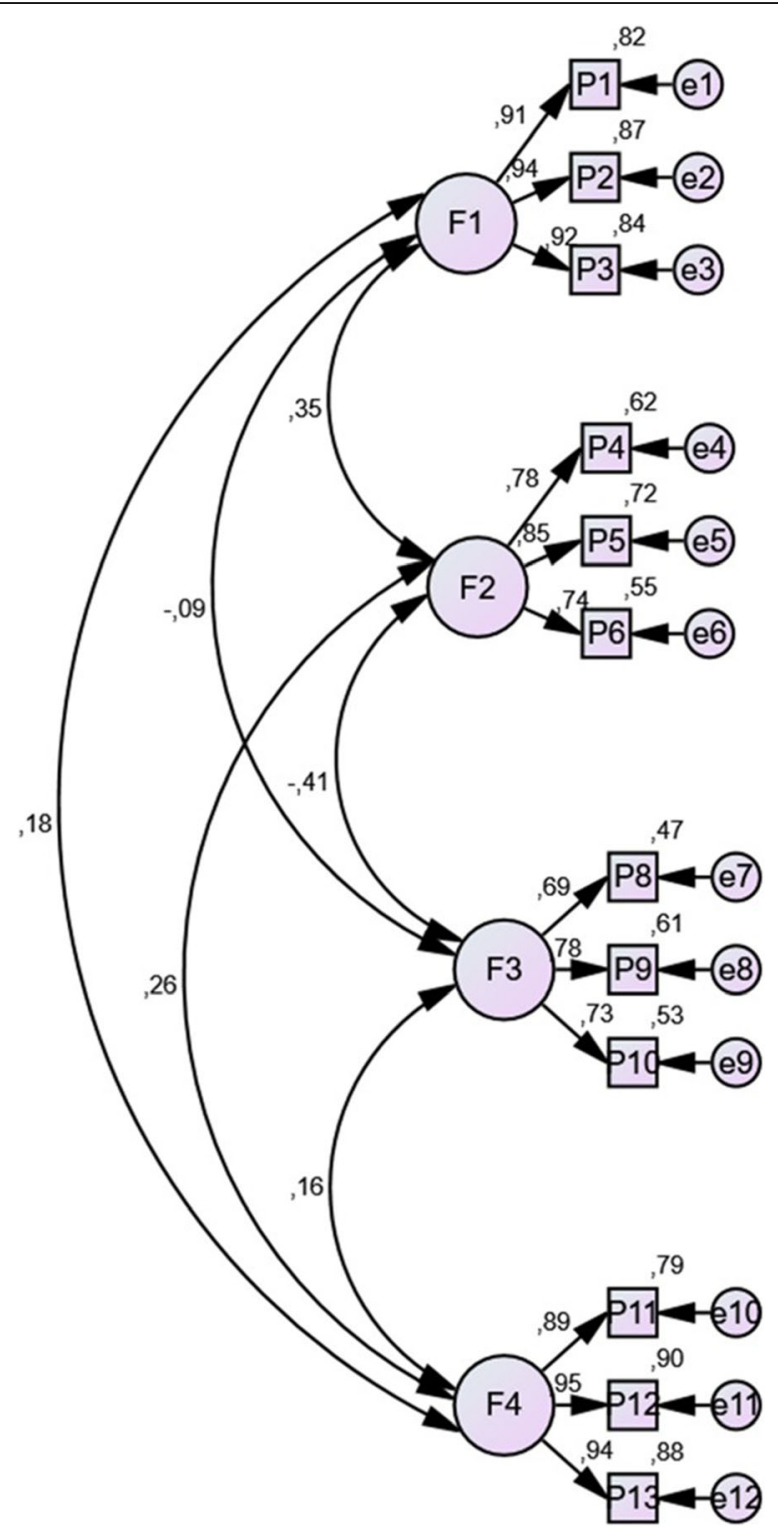

Fig. 1 Model 3- Unifactorial exclusion of the seventh item
Telemedicine has the potential to improve access to healthcare, especially in rural areas [32]. Regardless of its benefits, telemedicine has not been widely adopted. Readiness at various levels was the main factor determining the decision of health centers to not use telehealth "yet". Some centers stated that there were other priorities, such as building patient portals, and others were exploring the process of implementing telehealth [32]. Some patients have negative beliefs about telemedicine, with the main belief being that telemedicine can lead to medical errors [33]. Knowledge of telemedicine is an important key to identifying negative issues. Consequently, healthcare professionals need to learn and adapt their communication and technology for better results.

Evidence from the scientific literature shows that MT can be very useful for developing reliable instruments [34]. The syntax of the target questions was simple enough for rapid translation into a different language with acceptable results. In addition, participant characteristics and sample size ensure that this instrument was appropriate for validation. Another strength of the validation was the heterogeneity of the sample, with physicians with various medical specialties responding to the questionnaire.

The goodness of fit measures for model 3 were better than those for models 1 and 2. Our instrument had readability and validity according to the CFA. In contrast, the original instrument had only correlations between items.

A positive relationship between domains 1 and 2 was shown in the final model due to the positive selection in domain 2 but negative selection in domain 3. Likewise, there was a weaker positive relationship between domain 1 and domain 4 and a negative relationship of domain 3 with domains 1 and 2 .

There were some limitations to our study that need to be discussed. First, our population included only Ecuadorian physicians, and the sample may not be representative of other Hispanic countries. The original questionnaire this study derives its initial question set from does not possess a robust theoretical background for feature and domain selection. However, the concise methodology used allows for an adequate baseline to create a Spanish instrument. The study process included the removal of items to offer a simpler construct to derive a solid theoretical background from. The 
performance of the model suggests that the features selected represent to an adequate degree the problems addressed by the questionnaire. In the traditional questionnaire validation process, backwards translation is used for verification without a doubt that the original translation was valid. Considering that we used a machine learning model to perform the translation, its validity can be verified by switching the input and output. Therefore, the process of backwards translation was not formally performed in this study.

The original survey compiled 6 characteristic domains of the population and was validated using face and content validity methods. The original questionnaire had a Cronbach's alpha coefficient of 0.73 [9]. Additionally, our instrument exhibited an acceptable KMO and a significant Bartlett and explained the variance of the 4 dimensions with a strong significant association. Furthermore, our questionnaire, unlike the original questionnaire, was tested using chi square, RMSEA, TLI, NFI, PNFI, CFI, and PCFI, indicating goodness of fit.

Although the use of ICTs among clinicians is high [35], according to the results of our study, clinicians' knowledge about telemedicine is limited. Still with these results about knowledge of telemedicine, clinicians perceived that it is necessarily the use of it. The security of telemedicine is very important, and most clinicians agree that a framework should be created to prevent breaching data confidentiality. Additionally, the requirement of a formulated and clear framework for access to medical information and legal clarification for patients is needed. Previous studies showed similar results. Ashfaq et al. and Ayatollahi et al. concluded that clinicians' knowledge was also low, and the majority of them thought that the usage of telemedicine was necessary $[10,36]$.

\section{Conclusions}

Our study developed a translated and validated questionnaire to evaluate physician knowledge and perceptions of telemedicine. The translated instrument was clear, with adequate internal consistency, readability, and appropriate application in physician populations. We identified 12 items grouped into the four theoretical domains.

Our validated questionnaire could help to evaluate physicians' knowledge of telemedicine especially during the COVID-19 pandemic and thereby contribute to the development of tools that can increase the use of telemedicine technologies. We identified the perceptions and knowledge of Ecuadorian physician regarding Telemedicine and recommend that these should be validated in other Hispanic populations.

\section{Abbreviations}

CEISH: Comité de ética e Investigación en Seres Humanos; CFA: Confirmatory factor analysis; CFI: Comparative fit index; EFA: Exploratory factor analysis;

ICTs: Information and communication technologies; KMO: Kaiser-Meyer-Olkin;
MLE: Maximum likelihood estimation; MT: Machine translation; NFI: Normed fit index; PCFI: Parsimony comparative fit index; PNFI: Parsimony normed fit index; RMSEA: Root mean square error of approximation; TLI: Tucker Lewis index

\section{Supplementary Information}

The online version contains supplementary material available at https://doi. org/10.1186/s12889-021-11826-1.

Additional file 1.

\section{Acknowledgments}

The authors acknowledge Ayatollahi $\mathrm{H}$. et al. for allowing the use of the original questionnaire. Special thanks to all members of CENIT project Ecuador. Finally, we want to express our gratitude to Universidad Espiritu Santo for their continuous support.

\section{Authors' contributions}

ICO and GA coordinated the study. The design, acquisition, analysis, and interpretation of data was performed with substantial contributions from all participating authors. CV, CKY and NSP drafted the manuscript. The statistical analysis was performed by GA and CV. All authors contributed to edited drafts of this manuscript. All authors read and approved the final version of the manuscript.

\section{Funding}

The funds for the development of this research were provided by Universidad de Especialidades Espíritu Santo.

\section{Availability of data and materials}

The datasets used and analyzed during the current study are available from the corresponding author on reasonable request.

\section{Declarations}

Ethics approval and consent to participate

This study was approved by Comité de ética e Investigación en Seres Humanos (CEISH), ethical review board, Guayaquil-Ecuador (\#HCK-CEISH-180060). Informed consent was obtained from every participant.

\section{Consent for publication}

Ayatollahi H. et al. gave written consent via e-mail for the use of the questionnaire.

\section{Competing interests}

The authors declare that they have no conflicts of interest.

Received: 16 December 2020 Accepted: 20 September 2021

Published online: 02 October 2021

\section{References}

1. Schaper LK, Pervan GP. ICT and OTs: a model of information and communication technology acceptance and utilisation by occupational therapists. Int J Med Inf. 2007;76:S212-21. https://doi.org/10.1016/j.jimedinf.2 006.05.028.

2. Combi C, Pozzani G, Pozzi G. Telemedicine for developing countries: a survey and some design issues. Appl Clin Inform. 2016;07(04):1025-50. https://doi.org/10.4338/ACl-2016-06-R-0089.

3. Wilder-Smith A, Freedman DO. Isolation, quarantine, social distancing and community containment: pivotal role for old-style public health measures in the novel coronavirus (2019-nCoV) outbreak. J Travel Med. 2020;27(2): taaa020.

4. Wosik J, Fudim M, Cameron B, Gellad ZF, Cho A, Phinney D, et al. Telehealth transformation: COVID-19 and the rise of virtual care. J Am Med Inform Assoc. 2020;27(6):957-62. https://doi.org/10.1093/jamia/ocaa067.

5. Portnoy J, Waller M, Elliott T. Telemedicine in the era of COVD-19. J Allergy Clin Immunol Pract. 2020;8(5):1489-91. https:/doi.org/10.1016/j.jaip.2020.03.008. 
6. Smith AC, et al. Telehealth for Global Emergencies: Implications for Coronavirus Disease 2019 (COVID-19). J Telemed Telecare. 2020;26(5):30913. https://doi.org/10.1177/1357633X20916567

7. Giavina Bianchi M, Santos AP, Cordioli E. The majority of skin lesions in pediatric primary care attention could be managed by Teledermatology. PloS One. 2019;14(12):e0225479.

8. Hjelm NM. Benefits and drawbacks of telemedicine. J Telemed Telecare. 2005;11(2):60-70. https://doi.org/10.1258/1357633053499886.

9. Aldunate R, Nussbaum M. Teacher adoption of technology. Comput Hum Behav. 2013;29(3):519-24. https://doi.org/10.1016/j.chb.2012.10.017.

10. Ayatollahi H, Sarabi FZP. Clinicians' Knowledge and Perception of Telemedicine Technology. 2015;16:11-5.

11. Kuo K-M, Talley PC, Lee C-M, Yen Y-C. The influence of telemedicine experience on physicians' perceptions regarding adoption. Telemed EHealth. 2015;21(5):388-94. https://doi.org/10.1089/tmj.2014.0091.

12. Sami U, Maghazil AM, Qureshi AZ, Tantawy S, Moukais IS, Aldajani AA. Telemedicine and e-Health. 2021;27(5):587-91.

13. Aamodt IT, Lycholip E, Celutkiene J, Strömberg A, Atar D, Falk RS, et al. Health care professionals' perceptions of home Telemonitoring in heart failure care: cross-sectional survey. J Med Internet Res. 2019;21(2):e10362. https://doi.org/10.2196/10362.

14. Alaboudi A, Atkins A, Sharp B, Balkhair A, Alzahrani M, Sunbul T. Barriers and challenges in adopting Saudi telemedicine network: the perceptions of decision makers of healthcare facilities in Saudi Arabia. J Infect Public Health. 2016;9(6):725-33. https://doi.org/10.1016/j.jiph.2016.09.001.

15. de Souza CHA, Morbeck RA, Steinman M, Hors CP, Bracco MM, Kozasa EH, et al. Barriers and benefits in telemedicine arising between a hightechnology hospital service provider and remote public healthcare units: a qualitative study in Brazil. Telemed E-Health. 2017;23(6):527-32. https://doi. org/10.1089/tmj.2016.0158.

16. Suhr DD. Exploratory or Confirmatory Factor Analysis? Cary: SAS Institute; 2006. Internet resource http://www2.sas.com/proceedings/sugi31/200-31. pdf.

17. Cherrez-Ojeda I, Haddad M, Vera Paz C, Valdevila Figueira JA, Fabelo Roche J, Orellana Román C, et al. Spanish validation of the revised depression attitude questionnaire (R-DAQ). Psychol Res Behav Manag. 2019;12:1051-8. https://doi.org/10.2147/PRBM.S228249.

18. Alvarado-Villa GE, Moncayo-Rizzo JD, Gallardo-Rumbea JA. Spanish validation endorsement of SDM-Q-9, a new approach. BMC Public Health. 2019;19(1):106. https://doi.org/10.1186/s12889-019-6436-7.

19. Valdivieso Portilla DL, Gonzalez Rosero A, Alvarado-Villa G, Moncayo-Rizzo J. Psychometric properties of the Bern illegitimate tasks scale - Spanish version. Front Psychol. 2021;12:593870. https://doi.org/10.3389/fpsyg.2021. 593870.

20. Yang $Y$, Wang $X$. Modeling the intention to use machine translation for student translators: an extension of technology acceptance model. Comput Educ. 2019;133:116-26. https://doi.org/10.1016/j.compedu.2019.01.015.

21. Vogel S, Draper-Rodi J. The importance of pilot studies, how to write them and what they mean. Int J Osteopath Med. 2017;23:2-3. https://doi.org/10.1 016/j.ijosm.2017.02.001

22. Williams B, Onsman A, Brown T. Exploratory factor analysis: A five-step guide for novices. Australas J Paramed. 2010;8(3) [cited 2020 Jul 24] Available from: http://ajp.paramedics.org/index.php/ajp/article/view/93.

23. Courtney M, Gordon R. Determining the Number of Factors to Retain in EFA: Using the SPSS R-Menu v2 0 to Make More Judicious Estimations. [cited 2020 Jul 23]; Available from: https://scholarworks.umass.edu/pare/vol1 8/iss $1 / 8 /$

24. Taber KS. The use of Cronbach's alpha when developing and reporting research instruments in science education. Res Sci Educ. 2018;48(6):1273-96. https://doi.org/10.1007/s11165-016-9602-2.

25. Tavakol M, Dennick R. Making sense of Cronbach's alpha. Int J Med Educ. 2011;2:53-5. https://doi.org/10.5116/ijme.4dfb.8dfd.

26. Sun J. Assessing goodness of fit in confirmatory factor analysis. Meas Eval Couns Dev. 2005;37(4):240-56. https://doi.org/10.1080/07481756.2005.11 909764

27. Schermelleh-Engel K, Moosbrugger $H$, Müller $H$. Evaluating the Fit of Structural Equation Models: Tests of Significance and Descriptive Goodnessof-Fit Measures. Methods Psychological Res Online. 2003;8(2):52.

28. Fernández AM. Lecturabilidad de Fernández Huerta. Legible. 2016 [cited 2021 Feb 25]. Available from: https://legible.es/blog/lecturabilidad-ferna ndez-huerta/
29. Fernández AM. Analizador de legibilidad de texto. Legible. 2016 [cited 2020 Jul 23]. Available from: https://legible.es/

30. Iglesias C, Torgerson D. Does length of questionnaire matter? A randomised trial of response rates to a mailed questionnaire. J Health Serv Res Policy. 2000;5(4):219-21. https://doi.org/10.1177/135581960000500406.

31. Rolstad S, Adler J, Rydén A. Response burden and questionnaire length: is shorter better? A Review and Meta-analysis. Value Health. 2011;14(8):1101-8. https://doi.org/10.1016/j.jval.2011.06.003.

32. Lin C-CC, Dievler A, Robbins C, Sripipatana A, Quinn M, Nair S. Telehealth in health centers: key adoption factors, barriers, and opportunities. Health Aff (Millwood). 2018;37(12):1967-74. https://doi.org/10.1377/hlthaff.2018.05125.

33. Ly BA, Labonté $R$, Bourgeault IL. The beliefs of Senegal's physicians toward the use of telemedicine. Pan Afr Med J. 2019;34 [cited 2020 Aug 25] Available from: http://www.panafrican-med-journal.com/content/article/34/ 97/full/.

34. Zulfiqar S, Wahab MF, Sarwar MI, Lieberwirth I. Is machine translation a reliable tool for Reading German scientific databases and research articles? J Chem Inf Model. 2018;58(11):2214-23. https://doi.org/10.1021/acs.jcim. 8 b00534.

35. Cherrez-Ojeda I, Vanegas E, Felix M, Mata VL, Jiménez FM, Sanchez M, et al. Frequency of use, perceptions and barriers of information and communication technologies among Latin American physicians: an Ecuadorian cross-sectional study. J Multidiscip Healthc. 2020;13:259-69. https://doi.org/10.2147/JMDH.S246253.

36. Ashfaq A, Memon SF, Zehra A, Barry S, Jawed H, Akhtar M, et al. Knowledge and Attitude Regarding Telemedicine Among Doctors in Karachi. Cureus. 12(2) [cited 2020 Apr 6] Available from: https://www.ncbi.nlm.nih.gov/pmc/a rticles/PMC7065727/.

\section{Publisher's Note}

Springer Nature remains neutral with regard to jurisdictional claims in published maps and institutional affiliations.

Ready to submit your research? Choose BMC and benefit from

- fast, convenient online submission

- thorough peer review by experienced researchers in your field

- rapid publication on acceptance

- support for research data, including large and complex data types

- gold Open Access which fosters wider collaboration and increased citations

- maximum visibility for your research: over $100 \mathrm{M}$ website views per year

At $\mathrm{BMC}$, research is always in progress.

Learn more biomedcentral.com/submissions 